\title{
Lise Öğretmenlerinin Örgütsel Kimlik Algılarının Bazı Değişkenler Açısından İncelenmesi*
}

Önder ŞANLI, Dr., Malatya MEM, ondersanli44@hotmail.com

i. Bakır ARABACI, Doç. Dr., Fırat Üniversitesi Eğitim Fakültesi, bakirarabaci@hotmail.com

Öz: Bu araştırmada, lise öğretmenlerinin örgütsel kimlik algıları belirlenmeye çalışılmıştır. Tarama modelinde olan bu araştırmanın evrenini 2012-2013 eğitim - öğretim yılında Malatya il merkezinde ve ilçelerinde görev yapan 3730 lise öğretmeni oluşturmaktadır. Malatya il merkezi ve 6 ilçesindeki liselere uygulanan 521 ölçek veri analizine uygun görülmüştür. Öğretmenlerin cinsiyet, okul türü, görev yeri, mesleki kıdem ve branş türü değişkenleri ile örgütsel kimlik algılarına etkileri bakımından analizler yapılmıştır. Araştırmaya katılan öğretmenlerin cinsiyet değişkeni ile örgütsel kimlik algıları arasındaki fark istatistiksel açıdan anlamlı bulunmuştur. Ancak, öğretmenlerin örgütsel kimlik algı düzeylerinin okul türü, görev yeri, meslek kıdemi ve branş değişkenlerine göre gruplar arası fark istatistiksel açıdan anlamlı bulunmamıştır.

Anahtar Kelimeler: ortaöğretim kurumları, örgütsel kimlik, öğretmen algıları

\section{Examination of The Organizational Identity Perceptions of The Teachers Working at High Schools in Terms of Some Variables}

Abstract: The aim of this resech is to determine the organizational identity perceptions of high school teachers. The target population of this research, which is in descriptive relational scanning model, consists of 3730 teachers working in high schools in 2012-2013 academic year in the city of Malatya and six towns. The sample of the research consists of 521 teachers who were selected randomly from the target population with simple cluster sampling method. The questionnaires, which were filled up 521 teachers, were found suitable for analyzing. The analysis were done in accordance to the gender, type of school, working place, professional seniority and branch variables. The effects of these variables on organizational identity were analyzed. The relation between gender variable and organizational identity was found statistically significant. But the relation between type of school, working place, professional seniority and branch variables on organizational identity were not found statistically significant.

Key Words: High schools, organizational identity, perceptions of teachers

\footnotetext{
* Bu çalışma Önder Şanlı’nın doktora tezinden geliştirilmiştir.
} 


\section{GíRiş}

Kimlik kavramı çoğunlukla bireyin benzersizliğini, özerkliğini, zaman içindeki sürekliliğini ve farklılığını belirtlemek amacıyla kullanılmaktadır. Çok genel ve çoğunlukla başvurulan görüş kimliğin "Ben kimim?" sorusuna cevap verdiği yönündedir (Tonder, 2004, s. 70). Kimlik, varlığımızın özet bir tanımıdır. Bunun iki dayanağı vardır. Birincisi, kimliğe sahip olanı işaret eden yani 'kimlik edinen'; ikincisi ise kimlik edineni tanımlayan 'kimlik veren' dir. Bu anlamda kimlik, kimlik edinen ve kimlik verenin özgün bir birleşimidir (Güleç, 2005, s. 74).

Bireylerin olduğu gibi örgütlerin de bir kimliği vardır. Hündür (2006), çalışmasında kimliği "Paylaşılan örgütsel kimliğin oluşmasında kimlik algısı önemli bir role sahiptir. Örgütsel kimlik algısı, çalışanın örgütün karakteri hakkındaki değerlendirmesi" olarak tanımlamıştır. Örgütsel kimlik; "Bir firmanın, örgüt ya da kuruluşun, bir ürün ya da hizmetin adının (markasının), yaptığı işin, bu işin yapılışındaki anlayışın, görsel ve beyinsel (fikir) olarak akıllarda, başarılı/başarısız, olumlu/olumsuz, güzel/çirkin olarak yerleşmiş şeklidir, tanımlanan kimliğidir" (Ak, 1998, s. 18). Kimlik "Örgütün kendini farklı paydaşlara sunuş şekli ve kendini diğer örgütlerden farklılaştırmada kullandığı bir araç." şeklinde de tanımlanmaktadır (Marwick, C. Fill, 1997, s. 397). Başka bir ifadeyle örgütsel kimlik, örgüt üyelerinin sosyal bir grup olarak kendilerini nası tanımladıklarının ve diğer örgütlerin üyelerinden nasıl ayrı gördüklerinin bir ifadesidir (Empson, 2004, s. 759).

Örgütsel kimlik, örgütte çalışanların davranışları, örgütün iletişim biçimleri, felsefesi ve görsel unsurlarından oluşur (Korkmaz, 2007, s. 87). Bu kimlikleri, örgütlerin farklılıklarını ortaya koymalarına ve tanınmalarına olanak sağlamaktadır. Örgüt kimliği bir örgütün temel biçimi, özelliği, karakteri ve kişiliğidir. Söz konusu bu öğeler o örgütü tanımlar, yönlendirir ve şekillendirir (Downey, 1987, s. 7).

Örgütsel kimlik denildiğinde birçok kişinin aklına gelen ilk şeyler kuruluşun logosu, kullandığı renkler, amblem gibi görsel unsurlar olmaktadır. Fakat bunlar örgütsel kimliği açıklamakta yetersiz kalmaktadır. Çünkü örgütsel kimlik yukarıda sayılan görsel unsurları içine alan örgütsel tasarımın yanı sıra, örgütsel iletişim, örgütsel davranış ve örgüt felsefesi öğelerinden meydana gelmektedir. Bu öğeler de birbirleriyle etkileşim içindedir. Bu öğelerin örgüte has bir biçimde kullanılması, o örgütün 'örgüt kimliğini' oluşturmaktadır (Okay, 2000, s. 38). Örgütsel kimlik, örgütün yapmış olduğu bütün faaliyetlerden ve ortak yönetimden meydana gelir. Wally Olins' e göre (1990), örgüt kimliği bir örgüte ait dört noktayı; kim olduğunu, ne yaptığını, nasıl yaptığını, kim için yaptığını yansıtabilmektedir. Örgütsel kimlik ile ilgili çalışmalar da yapan Fombrun ve Van Riel' e göre (2003), örgütsel kimlik; çalışanların firma için merkezi önemde algıladığı, firmayı çalışanların gözünde diğer firmalardan ayırt eden, geçmişi ve bugünü geleceğe bağlayan, kalıcı ve sürekli özelliklerdir.

Örgütler için olumlu bir kimliğe sahip olmanın önemi tartışılmaz bir durum haline gelmiştir. Günümüzün yoğun rekabet koşullarında örgütleri birbirinden ayıran ve birini diğerinden üstün kılan unsurların belki de en başında o örgütün sahip olduğu kimlik gelmektedir. Günümüzde eğitim kurumlarının da kendilerine ait kimliğinin bulunması, bu kimliğin örgütsel davranışı şekillendirmesi, yön vermesi gerekmektedir. Okula devam eden öğrencilerin gelişim düzeyi, öğrencileri mesleğe ve yükseköğretime hazırlama işlevleri dikkate alındığında liselerin güçlü bir örgütsel kimliğe sahip olmaları önem taşımaktadır. Liselere ait kimliğin de okulun en önemli ögesi olan öğretmenler tarafından nasıl algılandığının araştırılması önem taşımaktadır. 


\subsection{Araştırmanın Amacı}

$\mathrm{Bu}$ araştırmanın amacı; lise öğretmenlerinin örgütsel kimlik algılarını belirlemek, öğretmenlerin örgütsel kimlik algılarının; cinsiyet, okul türü, görev yeri, mesleki kıdem ve brans değişkenleri açııından farklılaşıp/farklılaşmadığını incelemektir. Araştırmanın genel amacını gerçekleştirmek ve test edilmek üzere aşağıdaki hipotezler geliştirmiştir:

H1: Lise öğretmenlerinin örgütsel kimlik algıları yüksek düzeydedir.

H2: Lise öğretmenlerinin cinsiyetleri ile örgütsel kimlik algıları arasında farklılık vardır.

H3: Lise öğretmenlerinin görev yaptıkları okul türleri ile örgütsel kimlik algıları arasında farklılık vardır.

H4: Lise öğretmenlerinin görev yerleri ile örgütsel kimlik algıları arasında farklııık vardır.

H5: Lise öğretmenlerinin mesleki kıdemleri ile örgütsel kimlik algıları arasında farklılık vardır.

H6: Lise öğretmenlerinin branşları ile örgütsel kimlik algıları arasında farklılık vardır.

\section{YÖNTEM}

Araştırma tarama modelinde tasarlanmıştır. Tarama modelleri, geçmişte ve halen var olan bir durumu varolduğu şekliyle betimlemeyi amaçlayan yaklaşımlardır. Araştırmaya konu olan olay, birey ya da nesne, kendi koşulları içinde var olduğu gibi tanımlanmaya çalışılır. Onları herhangi bir şekilde değiştirme, etkileme çabası gösterilmez. Bilinmek istenen şey vardır ve oradadır. Önemli olan onu uygun bir biçimde 'gözetip' belirlemektir. Tarama modelinde amaçların ifade ediliş biçimi genellikle soru cümleleri ile olur. Bunlar; 'Ne idi ?', 'Ne ile ilgilidir?' ve 'Neden oluşmaktadır?' gibi sorulardır (Karasar, 2002; s. 77).

Araştırmanın çalışma evrenini, Malatya il merkezi ve ilçe merkezindeki liselerde 20122013 öğretim yılında görev yapan öğretmenler oluşturmaktadır. Örnekleme yöntemi olarak oransız küme örnekleme yoluna gidilmiştir. Oransız küme örneklemede, evrendeki küme türlerinden herbirinden örneklem'e girenlerin sayısı, tümü ile şansa bırakılmıştır. (Karasar, 2005; s. 115). Araştırma evreninde yer alan il merkezinde görev yapan 2321 ve ilçe merkezindeki okullarda görev yapan 1409 öğretmen olmak üzere toplam 3730 öğretmenden seçkisiz küme örnekleme yöntemi ile örneklem grubu oluşturulmuştur. Araştırma kapsamındaki 3730 öğretmenden 600 öğretmene ölçek uygulanmış, uygulanan ölçeklerden 521' i değerlendirmeye alınmıştır. Değerlendirmeye alınan ölçekler evrendeki öğretmen sayısının \%14' ünü oluşturmaktadır. Katılımcıların araştırma amacı çerçevesinde sorgulanan özellikleri tablolar halinde aşağıda açıklanmıştır. Katılımcıların cinsiyet değişkeni bakımından dağılımı Tablo 1 'de gösterilmiştir.

Tablo 1

Katılımcıların Cinsiyet Değişkeni Açısından Dağılımı

\begin{tabular}{ccc}
\hline Cinsiyet & F & \% \\
\hline Erkek & 362 & 69.5 \\
Kadın & 159 & 30.5 \\
Toplam & 521 & 100 \\
\hline
\end{tabular}

Cinsiyet değişkenine göre katılımcıların dağılımına bakıldığında 521 öğretmenin 362' si erkek ve $159^{\prime}$ u kadındır. Erkek öğretmenler katılımcıların \%69,5' ni, kadın öğretmenler ise $\% 30,5^{\prime}$ ini oluşturmaktadır. Cinsiyet değişkeni bakımından araştırmaya katılanların büyük çoğunluğunu erkek öğretmenler olduğu görülmektedir. Katılımcıların mesleki kıdem bakımından dağılımı Tablo 2'de gösterilmiştir. 
Tablo 2

Katılımcıların Mesleki Kıdem Değişkeni Açısından Dağılımı

\begin{tabular}{ccc}
\hline Mesleki Kıdem & F & \% \\
\hline $1-5$ yıl & 96 & 18.4 \\
$6-10 \mathrm{yıl}$ & 99 & 19.0 \\
$11-15 \mathrm{yıl}$ & 141 & 27.1 \\
$16-20$ yıl & 110 & 21.1 \\
21 yıl ve üzeri & 75 & 14.4 \\
Toplam & $\mathbf{5 2 1}$ & $\mathbf{1 0 0}$ \\
\hline
\end{tabular}

Meslek kıdemi bakımından her gruptan belli bir sayıda öğretmenin katılımcılar arasında yer aldığı görülmektedir. En fazla katılımcının olduğu grup \%27.1 ile 11-15 yıl mesleki kıdeme sahip olan öğretmenler oluşurken, en az katılımcı ise \%14.4 ile 21 yıl ve üzeri mesleki kıdeme sahip olan öğretmenlerden oluşmuştur. Katılımcıların okul türü değişkeni bakımından dağılımı Tablo 3'te gösterilmiştir.

Tablo 3

Katılımcıların Okul Türü Değişkeni Açısından Dağılımı

\begin{tabular}{lcc}
\hline Okul Türü & F & \% \\
\hline Genel Lise & 397 & 76.2 \\
Meslek Lisesi & 124 & 23.8 \\
Toplam & $\mathbf{5 2 1}$ & $\mathbf{1 0 0}$ \\
\hline
\end{tabular}

Okul türü değişkenine göre katılımcıların dağılımına bakıldığında \%76,2' sını oluşturan 397 öğretmenin genel lisede ve \%23,8' ini oluşturan 124 öğretmenin meslek lisesinde görev yaptığı belirlenmiştir. Okul türü değişkeni bakımından araştırmaya katılanların büyük çoğunluğunun genel liselerde görev yapan öğretmenlerden oluştuğu görülmektedir. Katılımcıların branş değişkeni bakımından dağılımı Tablo 4'te gösterilmiştir.

Tablo 4

Katılımcıların Branş Türü Değişkenine Göre Dağılımı.

\begin{tabular}{lcc}
\hline Branş & F & \% \\
\hline Türk Dili & 98 & 18.8 \\
Beden Eğitimi & 22 & 4.2 \\
Felsefe & 19 & 3.6 \\
Rehberlik & 28 & 5.4 \\
Meslek Dersi & 34 & 6.5 \\
Bilişim & 13 & 2.5 \\
Resim & 7 & 1.3 \\
Almanca & 9 & 1.7 \\
Müzik & 7 & 1.3 \\
Din Kültürü & 20 & 3.8 \\
Tarih & 37 & 7.1 \\
Coğrafya & 30 & 5.8 \\
Matematik & 84 & 16.1 \\
Fizik & 22 & 4.2 \\
Kimya & 29 & 5.6 \\
Biyoloji & 20 & 3.8
\end{tabular}




\begin{tabular}{lcc} 
İngilizce & 41 & 7.9 \\
Toplam & $\mathbf{5 2 1}$ & $\mathbf{1 0 0 . 0}$ \\
\hline
\end{tabular}

Branş türü değişkenine göre katılımcıların \%18,8' ini Türk Dili ve \%16,1' ini Matematik branşındaki öğretmenler oluşturmaktadır. Okullarda branşlara göre öğretmen kadrolarının belirlenmesinde sınıflarda okutulan dersler ve derslerin haftalık ders saatleri etkili olduğundan Türk Dili ve Matematik branşları yüksek oranda çıkmıştır. Diğer branşlardaki öğretmenlerin sayılarında da genel olarak yine okullardaki haftalık ders saatleri etkili olmuştur. Bu duruma paralel oranda bir dağılım göstermiştir. Katılımcıların görev yeri değişkeni bakımından dağılımı Tablo 5'te gösterilmiştir.

Tablo 5

Katılımcıların Görev Yeri Değişkeni Açısından Dağılımı.

\begin{tabular}{lcc}
\hline Görev Yeri & F & \% \\
\hline İl Merkezi & 243 & 46.6 \\
İlçe & 278 & 53.4 \\
Toplam & $\mathbf{5 2 1}$ & $\mathbf{1 0 0}$ \\
\hline
\end{tabular}

Katılımcıların görev yeri değişkenine açısından \%53,4’ ü İlçe, \%46,6’ sı ise il merkezindeki okullarda görev yapan öğretmenlerden oluşmaktadır.

\subsection{Veri Toplama Aracı}

Veri toplama aracı olarak aslı Jones ve Volpe (2010), tarafından geliştirilen "Örgütsel kimlik ölçeği" kullanılmıştır. Ölçek iki araştırmacı tarafından Türkçeye çevrilmiş, daha sonra tekrar İngilizceye çevrilmiştir. İki araştırmacının çevirileri arasındaki uyum oldukça yüksektir. Bu çeviriler alan uzmanı iki akademisyen tarafından incelenmiş, akademisyenlerin önerileri doğrultusunda düzenlemeler yapılmıştır. Araştırmada kullanılan ölçeğin geçerlik ve güvenirlik çalışmaları yapılmıştır. Ölçeğin birinci bölümünde demografik faktörler: cinsiyet, kıdem, okul türü, branş türü ve görev yeri değişkenleri yer almıştır. Ölçeğin ikinci bölümünde örgütsel kimlik kapsamında 6 madde bulunmaktadır. Örgütsel Kimlik Ölçeğinin örneklem uygunluğunu belirlemek amacıyla Kaiser Meyer Olkin (KMO) değeri hesaplanmıştır. Yapılan analiz sonucunda KMO değeri (,778; p: .000) anlamlı bulunmuştur. Bu aşamadan sonra ölçeğin faktör yapısını belirlemek amacıyla açımlayııı faktör analizi yapılmıştır. Faktör analizi sonucunda ölçek maddelerinin tek faktör altında toplandığı görülmüştür. Örgütsel Kimlik Ölçeğinin faktör yapısı, ölçeğin açıkladığı varyans oranı ve ölçek için hesaplanan Cronbach Alpha güvenirlik katsayıları tablo 6' da sunulmuştur.

Örgütsel kimlik ölçeğinin madde yükleri, 36 ile, 59 arasında değişmektedir. Ölçeğin açıkladığı varyans oranı \% 47, 30' dur. Ölçeğin Cronbach Alpha güvenirlik katsayısı, 77'dir. Elde edilen sonuçlara göre ölçeğin güvenilir olduğu söylenebilir.

Ölçeğin farklı örneklemlerde farklı faktör yapılarına sahip olabileceği düşünülerek araştırma verilerini elde etmek için kullanılan örgütsel kimlik ölçeği için doğrulayıcı faktör analizi de yapılmıştır. Model uygunluğunun ölçümünde, önceden belirlenen modelin (teorik) elde edilen veriyi ne kadar iyi açıkladığı uyum iyiliği indeksleri ile belirlenir. Uyum iyiliği testleri modelin kabul ve red edilmesi kararının verildiği aşamadır. Eğer modelin tamamı uyum iyiliği testleri sonucunda red edilirse model içindeki katsayıların veya parametrelerin bir önemi kalmaz ve bunlar değerlendirilmez. Öncelikle bir modelin tamamının (overall) kabul edilmesi gerekir, bunun ardından katsayıların anlamlılığı irdelenebilir. LISREL programı 15 adet ve AMOS programı ise 25 adet uyum iyiliği testine yer vermektedir. Genelde bu uyum iyiliği indekslerinden en az 4 en fazla 8 tanesi model açıklanırken kullanılır. En çok kullanılan indeksler chisquare, GFI, NFI, CFI, NNFI, SRMR, AGFI, TLI, RMSEA' dır (Ayyıldız ve Cengiz, 
2006:77)

Tablo 6

Örgütsel Kimlik Ölçeğinin Faktör Yapısı, Açıklanan Varyans Oranı ve Güvenirlik Katsayısı.

No Madde $\quad$ Faktör

Yükleri

Madde 1 Birisi okulumu eleştirdiğinde, kişisel bir aşağılanma hissederim.

Madde 2 Başkalarının okulum hakkında ne düşündükleri ile çok ilgilenirim.

Madde 3 Bu okul hakkında konuşurken "onlar" diye konuşmaktan ziyade "biz" diye konuşurum.

Madde 4 Bu okulun başarıları benim başarılarımdır.

adde 5 Birileri bu okulu övdüğü zaman bunu kendime yapılmış bir övgü olarak hissederim.

Madde 6 Medya' da bu okulu eleştiren bir hikâye olursa utanırım.

Örgütsel kimlik ölçeğine ilşkin doğrulayıcı faktör analizi yapılmıştır. Örgütsel Kimlik Ölçeği için yapılan doğrulayıcı faktör analizi Şekil 1' de, elde edilen uyum iyiliği değeri tablo $7^{\prime}$ de sunulmuştur.

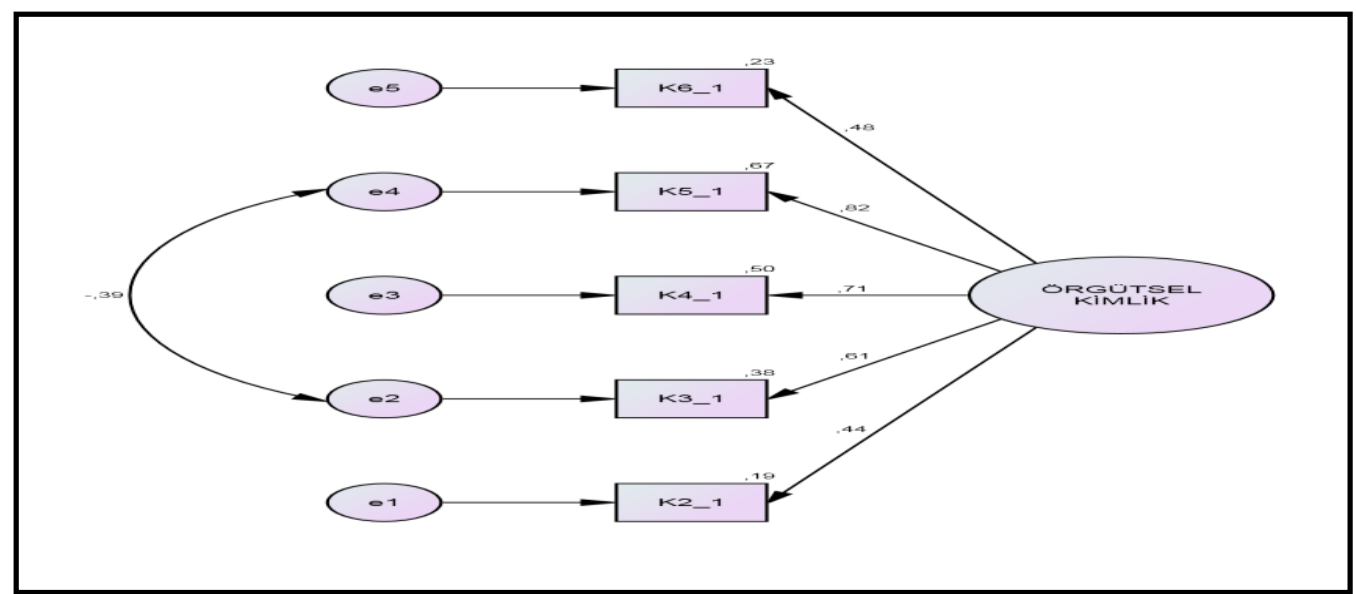

Şekil 1. Örgütsel Kimlik Ölçeği Doğrulayıcı Faktör Analizi.

Uyum indeksleri ve normal değerleri tablo 7'de görülmektedir.

Tablo 7

DFA'da Kullanılan Uyum Iyiliği Indeksleri ve Normal Değerleri

\begin{tabular}{lcc}
\hline & Kabul Edilebilir Değer & Indeks Normal Değer \\
\hline$\chi 2$ “p” Değeri & $p>0.05$ & - \\
$\chi 2 / \mathrm{sd}$ & $<2$ & $<5$ \\
$\mathrm{GFI}$ & $>0.95$ & $>0.90$ \\
\hline $\mathrm{AGFI}$ & $>0.95$ & $>0.90$ \\
$\mathrm{CFI}$ & $>0.95$ & $>0.90$ \\
\hline
\end{tabular}




\begin{tabular}{lll}
\hline RMSEA & $<0.05$ & $<0.08$ \\
RMR & $<0.05$ & $<0.08$ \\
SRMR & $<0.05$ & $<0.08$ \\
\hline
\end{tabular}

Kaynak: (Şimşek, 2007)

Örgütsel kimlik ölçeği uyum iyiliği değerlerine ilişkin veriler Tablo 8'de gösterilmiştir.

Tablo 8

Örgütsel Kimlik Ölçeği Uyum Iyiliği Değerleri

\begin{tabular}{cccccccc}
\hline Ölçek & CMIN/DF & GFI & AGFI & CFI & NFI & TLI & RMSEA \\
\hline Örgütsel Kimlik & 2.030 & 994 & .977 & .992 & .985 & .981 & .053 \\
\hline
\end{tabular}

Örgütsel Kimlik Ölçeği için yapılan doğrulayıcı faktör analizi sonucunda ölçekten bir madde (1. Madde) faktör yükünün 1.00'ın üzerinde olmasından (2.838) ve ölçeğin toplam kümülatif değerini \%50'nin altına düşürdüğünden (\%47.304) dolayı faktör analizinden çıkartılmıştır. Analiz sonucunda ölçek beş maddeden oluşmuştur. Elde edilen uyum iyiliği değerlerine bakıldığında, CMIN/DF 2,030 değeri ile 2,1 ile 3,1 aralığında olduğundan model kabul edilebilir yeterliktedir. Yaklaşık Hataların Ortalama Karakökü (RMSEA) incelendiğinde ise, .053 düzeyinde bir uyum indeksi elde edildiği görülmektedir. RMSEA'nın aldığı değer model uyum kabul edilebilir düzeydedir. İyilik Uyum İndeksi (GFI) ,994 ve Düzenlenmiş İyilik Uyum İndeksi (AGFI)' nin ,977 olduğu görülmektedir. GFI ve AGFI değeri, 95 ve üzerinde olduğundan mükemmel düzeyde uyum değeri olduğu söylenebilir. Normlaştırılmış Uyum İndeksi (NFI) ,985 ve Karşılaştırmalı Uyum İndeksi (CFI) .992 olduğu görülmektedir. NFI ve CFI değerleri $95^{\prime}$ in üzerinde olduğundan mükemmel düzeyde uyum iyiliğine sahip olduğu söylenebilir. Bu değerlerin belirlenen uyum indekslerine sahip olduğu söylenebilir (Bayram, 2010; Çokluk, Şekercioğlu ve Büyüköztürk, 2010; Şimşek, 2007; Sümer, 2000).

Araştırmada kullanılan ölçek, Likert tipi beşli dereceleme ile derecelenmiştir. Derecelendirme aralıkları; değer farkının değer yargısına bölünmesiyle elde edilen $4 / 5=0,80^{\prime}$ lik aralık değerine göre yorumlanmış, ilgili istatistik tablo 9' da gösterilmiştir.

Tablo 9

Ölç̧ek Maddelerinin Derecelendirme Ölçütü

\begin{tabular}{cccc}
\hline Değer & Seçenek & Aralık & Düzey \\
\hline $\mathbf{1}$ & Kesinlikle Katılmıyorum & $1.00-1.80$ & Çok Düşük \\
$\mathbf{2}$ & Katılmıyorum & $1.81-2.60$ & Düşük \\
$\mathbf{3}$ & Kararsızım & $2.61-3.40$ & Orta \\
$\mathbf{4}$ & Katılıyorum & $3.41-4.20$ & Yüksek \\
$\mathbf{5}$ & Kesinlikle Katılıyorum & $4.21-5.00$ & Çok Yüksek \\
\hline
\end{tabular}

\subsection{Verilerin Analizi}

Verilerin analizinde SPSS 20.0 programı kullanılmıştır. Araştırma ölçeğinin doğrulayıcı faktör analizleri yapıldıktan sonra öğretmenlerin cinsiyet, kıdem, okul türü, branş türü ve görev yeri değişkenleri açısından grup ortalamaları arasında anlamlı farklılıkların bulunup bulunmadığı amacıyla " $\mathrm{t}$ " testi ve dağılımın homojen olmadığı durumlarda Mann Whitney U testleri yapılmıştır. Branş türü ve kıdem değişkenleri açısından ortalamalar arasında anlamlı farklılıkların bulunup bulunmadığı amacıyla tek yönlü varyans analizi (One Way ANOVA) ve Kruskal Wallis testleri yapılmıştır. Varyansların eşit varsayıldığı durumda tek yönlü varyans analizi, eşit varsayılmadığı durumlarda Kruskal Wallis testleri uygulanmıştır. Anlamlılık testlerinde $p<0,05$ anlamlılık düzeyine göre değerlendirmeler yapılmıştır. 


\section{BULGULAR VE YORUMLAR}

Bu bölümde, araştırma amacı kapsamında oluşturulan hipotez testlerine ilişkin sonuçlara ve yorumlara yer almaktadır.

H1: “Öğretmenlerin örgütsel kimlik algıları yüksektir” hipotezine ilişkin bulgular:

Lise öğretmenlerinin örgütsel kimlik algılarına ilişkin genel bilgiler Tablo $10^{\prime}$ da sunulmuştur.

Tablo 10.

Örgütsel Kimliği Oluşturan Maddelerin Frekans (F) Yüzde (\%) Ortalama ( $\bar{X}$ ) ve Standart Sapma (Ss) Değerleri

\begin{tabular}{|c|c|c|c|c|c|c|c|}
\hline \multirow[t]{2}{*}{ Madde No } & 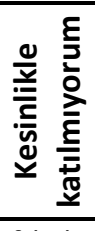 & 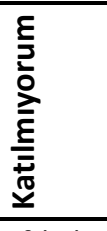 & $\frac{\varepsilon}{\underline{\underline{N}}}$ & 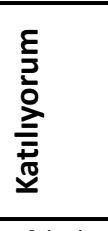 & 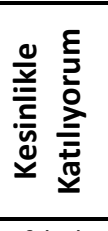 & \multirow[b]{2}{*}{$\bar{X}$} & \multirow[b]{2}{*}{ Ss } \\
\hline & $f(\%)$ & $f(\%)$ & $f(\%)$ & $f(\%)$ & $f(\%)$ & & \\
\hline $\begin{array}{l}\text { 1. Başkalarının okulum hakkında ne } \\
\text { düşündükleri ile çok ilgilenirim. }\end{array}$ & $\begin{array}{c}50 \\
(9.6)\end{array}$ & $\begin{array}{c}95 \\
(18.2)\end{array}$ & $\begin{array}{c}56 \\
(10.7)\end{array}$ & $\begin{array}{c}252 \\
(48.4)\end{array}$ & $\begin{array}{c}68 \\
(13.1)\end{array}$ & 3.37 & 1.19 \\
\hline $\begin{array}{l}\text { 2. Bu okul hakkında konuşurken } \\
\text { "onlar" diye konuşmaktan ziyade "biz" } \\
\text { diye konuşurum. }\end{array}$ & $\begin{array}{c}39 \\
(7.5)\end{array}$ & $\begin{array}{c}37 \\
(7.1)\end{array}$ & $\begin{array}{c}42 \\
(8.1)\end{array}$ & $\begin{array}{c}219 \\
(42.0)\end{array}$ & $\begin{array}{c}184 \\
(35.3)\end{array}$ & 3.91 & 1.17 \\
\hline $\begin{array}{l}\text { 3. Bu okulun başarıları benim } \\
\text { başarılarımdır. }\end{array}$ & $\begin{array}{c}40 \\
(7.7)\end{array}$ & $\begin{array}{c}73 \\
(14.0)\end{array}$ & $\begin{array}{c}59 \\
(11.3)\end{array}$ & $\begin{array}{c}222 \\
(42.6)\end{array}$ & $\begin{array}{c}127 \\
(24.4)\end{array}$ & 3.62 & 1.21 \\
\hline $\begin{array}{l}\text { 4. Birileri bu okulu övdüğü zaman } \\
\text { bunu kendime yapılmış bir övgü olarak } \\
\text { hissederim. }\end{array}$ & $\begin{array}{c}30 \\
(5.8)\end{array}$ & $\begin{array}{c}109 \\
(20.9)\end{array}$ & $\begin{array}{c}66 \\
(12.7)\end{array}$ & $\begin{array}{c}218 \\
(41.8)\end{array}$ & $\begin{array}{c}98 \\
(18.8)\end{array}$ & 3.47 & 1.18 \\
\hline $\begin{array}{l}\text { 5. Medyada bu okulu eleştiren bir } \\
\text { hikâye olursa utanırım. }\end{array}$ & $\begin{array}{c}37 \\
(7.1)\end{array}$ & $\begin{array}{c}88 \\
(16.9)\end{array}$ & $\begin{array}{c}34 \\
(6.5)\end{array}$ & $\begin{array}{c}217 \\
(41.7)\end{array}$ & $\begin{array}{c}145 \\
(27.8)\end{array}$ & 3.66 & 1.24 \\
\hline Toplam: & & & & & & 3.60 & 1.19 \\
\hline
\end{tabular}

Örgütsel kimliğe ilişkin "Bu okul hakkında konuşurken 'onlar' diye konuşmaktan ziyade 'biz' diye konuşurum" maddesinde ortalamanın $\overline{\mathrm{X}}=3,91$ ile yüksek düzeyde olduğu görülmektedir. Katılımcıların bu madde için ölçme aracındaki seçeneklerden "Kesinlikle katılıyorum." için \%35,3 ve "Katılıyorum." için \%42,0 oranında görüş bildirdiği belirlenmiştir. Araştırmaya katılan öğretmenlerin örgütsel kimlik algı düzeylerinin ortalamaları incelendiğinde; "Bu okul hakkında konuşurken 'onlar' diye konuşmaktan ziyade 'biz' diye konuşurum." $\overline{\mathrm{X}}$ $=3,91 \pm 1,17$; "Medyada bu okulu eleştiren bir hikâye olursa utanırım." $\bar{X}=3,66 \pm 1,24$; "Bu okulun başarıları benim başarılarımdır." $\bar{X}=3,62 \pm 1,21$; "Birileri bu okulu övdüğü zaman bunu kendime yapılmış bir övgü olarak hissederim." $\bar{X}=3,47 \pm 1,18$; "Başkalarının okulum hakkında ne düşündükleri ile çok ilgilenirim." $\bar{X}=3,37 \pm 1,19$ olduğu belirlenmiştir.

Ortaöğretim kurumlarında çalışan öğretmenlerin örgütsel kimlik algılarına ilişkin genel ortalamanın ( $\bar{X}=3,60, \pm=1,19)$ "Katılıyorum." yüksek düzeyde olduğu görülmektedir. Böylece, H1 hipotezi kabul edilmiştir. Öğretmenlerin örgütsel kimlik algılarının yüksek düzeyde olması sevindirici bir durumdur. İnsanlar bir örgüt ile kendilerini özdeşleştirdiklerinde veya bunlara karşı güçlü kimlik algısı beslediklerinde bu örgütlerin gerçekleştirdiği faaliyetler, önemli sayılan tutum ve inançlar bu bireyler üzerine yansıyarak bireylerin inanç, tutum ve davranışlarını etkilemektedir (Ertürk, 2003, s. 149).

H2: "Lise öğretmenlerinin cinsiyetleri ile örgütsel kimlik algıları arasında farklılık vardır." hipotezine ilişkin bulgular: 
Araştırmaya katılan öğretmenlerin cinsiyet değişkeni ile örgütsel kimlik algıları arasında fark olup olmadığını belirlemeye yönelik olarak yapılan t testi sonuçları tablo 11 'da gösterilmiştir.

Tablo 11

Örgütsel Kimlik Iç̧in Cinsiyet Değişkenine Göre Yapılan t Testi Sonuçları

\begin{tabular}{lcccccc}
\hline \multicolumn{1}{c}{ Cinsiyet } & $\mathbf{N}$ & $\bar{X}$ & Ss & sd & t & p \\
\hline Erkek & 362 & 3.69 & 0.84 & 519 & 3.084 & $.002^{*}$ \\
Kadın & 159 & 3.44 & 0.81 & & & \\
\hline
\end{tabular}

Araştırmaya katılan öğretmenlerin cinsiyet değişkeni ile örgütsel kimlik algıları arasındaki fark istatistiksel açıdan anlamlı bulunmuştur ( $p<0.05)$. Böylece H2 hipotezi kabul edilmiştir. Cinsiyet değişkeni bakımından erkek öğretmenlerin örgütsel kimlik algısına ilişkin cevaplarının ortalaması $\bar{X}=3,69, \pm 0,84$ iken; kadın öğretmenlerin cevaplarının ortalaması $\bar{X}=3,44, \pm 0,81$ olup erkek öğretmenlere oranla daha düşük olduğu görülmektedir. Örgütsel kimlik, bireyin kendisini tanımladığı kavramlarla örgütü tanımladığı kavramlar arasındaki benzerliğin derecesi olarak ortaya çıkmaktadır (Ertürk, 2003, s. 149). Erkek öğretmenlerin okullarıyla özdeşleşme, okulun kimliğinde kendini tanımlayabilme düzeyleri bakımından kadın öğretmenlerden daha ileri olduğu söylenebilir. Bu durumun giderilmesine yönelik olarak; kadın öğretmenlere okullarının misyonunu ve vizyonunu daha açık olarak anlayabilmelerine yönelik öğretmenlerin tamamının katıldıkları ortak kimlik oluşturmanın önemini içeren etkinlikler de yapılabilir.

H3: "Lise öğretmenlerinin görev yaptıkları okul türleri ile örgütsel kimlik algıları arasında farklılık vardır" hipotezine lişkin bulgular:

Araştırmaya katılan öğretmenlerin okul türleri ile örgütsel kimlik algıları arasında fark olup olmadığını belirlemeye yönelik olarak yapılan t testi sonuçları tablo 12 'de gösterilmiştir.

Tablo 12.

Örgütsel Kimlik Için Öğretmenlerin Görev Yaptikları Okul Türü Değişkenine Göre Yapılan t Testi Sonuçları

\begin{tabular}{lcccccc}
\hline Okul Türü & $\mathbf{N}$ & $\bar{X}$ & Ss & sd & t & p \\
\hline Genel Lise & 397 & 3.62 & 0.83 & 519 & .796 & .426 \\
Meslek Lisesi & 124 & 3.56 & 0.84 & & & \\
\hline
\end{tabular}

Araştırmaya katılan öğretmenlerin görev yaptıkları okul türü değişkenine ilişkin örgütsel kimlik algıları arasındaki fark istatistiksel açıdan anlamlı bulunmamıştır ( $p>0.05)$. Böylece H3 hipotezi reddedilmiştir. Okul türü değişkeni bakımından genel lisede görev yapan öğretmenlerin örgütsel kimlik algısına ilişkin cevaplarının ortalaması $\bar{X}=3,62, \pm 0,83$ ve meslek lisesinde görev yapan öğretmenlerin cevaplarının ortalaması $\bar{X}=3,56, \pm 0,84$ olup, iki grubun ortalamasının birbirine yakın olduğu görülmektedir.

Ayrıca örneklem seçilen okullar bakımından genel liselerde görev yapan öğretmenlerin \%76,2 oranında olması ki, okulların oransal dağılımı bu şekildedir. Bu durumun oluşmasında meslek liselerinde görev yapan meslek dersi branşı dışındaki öğretmenlerin sayıca fazla olması da dikkate alınmalıdır. Meslek liseleri için atölye ve bölümlerde eğitim-öğretim yapan meslek dersi öğretmenleri ile aynı okuldaki dersliklerde öğretim yapan kültür dersleri öğretmenleri okul içinde farklı bölümlerde farklı kültürler de geliştirmektedirler. Yalnızca meslek dersi öğretmenlerini kapsayan bir çalışmada farklı bulgulara da ulaşılabilir.

H4: "Lise öğretmenlerinin görev yerleri ile örgütsel kimlik algıları arasında farklılık vardır." hipotezine lişkin bulgular:

Araştırmaya katılan öğretmenlerin görev yeri değişkeni ile örgütsel kimlik algıları 
arasında fark olup olmadığını belirlemeye yönelik olarak yapılan t testi sonuçları tablo 13 'de gösterilmiştir.

Tablo 13.

Örgütsel Kimlik Içcin Görev Yeri Değişkenine Göre Yapılan t Testi Sonuçları

\begin{tabular}{lcccccc}
\hline Görev Yeri & $\mathbf{N}$ & $\bar{X}$ & Ss & sd & t & p \\
\hline II Merkezi & 243 & 3.59 & 0.86 & 519 & -.429 & .668 \\
ilçce Merkezi & 278 & 3.63 & 0.82 & & & \\
\hline
\end{tabular}

Araştırmaya katılan öğretmenlerin görev yeri değişkenine örgütsel kimlik algıları arasındaki fark istatistiksel açıdan anlamlı bulunmamıştır $(p>0.05)$. Böylece H4 hipotezi reddedilmiştir. Görev yeri değişkeni bakımından il merkezinde görev yapan öğretmenlerin örgütsel kimlik algısına ilişkin cevaplarının ortalaması $\bar{X}=3,59, \pm 0,86$ ve ilçe merkezinde görev yapan öğretmenlerin cevaplarının ortalaması $\bar{X}=3,63, \pm 0,82$ olup, iki grubun ortalamasının birbirine yakın olduğu görülmektedir.

Örgütsel kimliğe ilişkin algıları bakımından öğretmenlerin il veya ilçe merkezinde çalışıyor olmalarının etkili olmadığı belirlenmiştir. Araştırma kapsamına alınan il ve ilçe merkezindeki okulların büyüklüğü ayrıca dikkate alınmamıştır. Ancak örgüt büyüklüğü ile örgüte bağlılık arasında da bir ilişki olduğu ileri sürülmüştür. İş görenler, büyük örgütlerle kendilerini özdeşleştirmekte güçlük çekmektedir (Çırpan, 1999, s. 64).

H5: "Lise öğretmenlerinin mesleki kıdemleri ile örgütsel kimlik algıları arasında farklılık vardır." hipotezine ilişkin bulgular:

Araştırmaya katılan öğretmenlerin mesleki kıdem değişkeni ile örgütsel kimlik algıları arasında fark olup olmadığını belirlemeye yönelik olarak yapılan t testi sonuçları tablo 14 'de gösterilmiştir.

Tablo 14

Örgütsel Kimlik Için Mesleki Kıdem Değişkenine Göre Yapılan Tek Yönlü Varyans Analizi (ANOVA) Sonuçları

\begin{tabular}{ccccccc}
\hline Mesleki Kıdem & $\mathbf{N}$ & $\bar{X}$ & Ss & sd & $\mathbf{F}$ & $\mathbf{p}$ \\
\hline $\mathbf{1 - 5}$ yıl & 96 & 3.51 & 0.81 & 516 & 1.479 & .207 \\
$\mathbf{6 - 1 0}$ yıl & 99 & 3.66 & 0.82 & & & \\
$\mathbf{1 1}-\mathbf{1 5}$ yıl & 141 & 3.58 & 0.82 & & & \\
$\mathbf{1 6}-\mathbf{2 0}$ yıl & 110 & 3.76 & 0.83 & & & \\
$\mathbf{2 0}$ yıl üstü & 75 & 3.53 & 0.89 & & & \\
\hline Toplam & $\mathbf{5 2 1}$ & $\mathbf{3 . 6 1}$ & $\mathbf{0 . 8 3}$ & & & \\
\cline { 1 - 3 }
\end{tabular}

Araştırmaya katılan öğretmenlerin örgütsel kimlik algı düzeylerinin meslek kıdemi değişkenine göre tek yönlü varyans analizi sonucunda grup ortalamaları arasındaki fark istatistiksel açıdan anlamlı bulunmamıştır ( $p>0.5)$. Böylece, H5 hipotezi reddedilmiştir.

Öğretmenlerin örgütsel kimlik algı düzeylerinin kıdem değişkenine göre ortalamalarının birbirine yakın düzeyde olduğu görülmektedir. En yüksek ortalamanın 16-20 yıl kıdemi olanlarda ve en düşük ortalamanın da 1-5 yıl kıdemi olanlarda olduğu belirlenmiştir. Mesleki yaşamlarının henüz başında olan 1-5 yıl kıdemi olan öğretmenlerin belli bir süre çalıştıktan sonra okulları ile ilgili kimlik algılarının değiştiği söylenebilir. Kimlik, örgütlerin bir anda kolaylıkla edinebilecekleri veya değiştirebilecekleri bir unsur değildir. Oluşumu ve değişimi uzun vadeli ve planlı halkla ilişkiler çalışmalarını gerektirmektedir (Biber 2003, s. 79-80).Tüm bu çabaların en fazla sergilenmesi gereken dönemin öğretmenlik mesleğinin ilk yılları olduğu, bu araştırmanın da önemli sonuçlarındandır. 


\section{H6: "Lise öğretmenlerinin branşları ile örgütsel kimlik algıları arasında farklılık vardır." hipotezine ilişkin bulgular:}

Araştırmaya katılan öğretmenlerin branş değişkeni ile örgütsel kimlik algıları arasında fark olup olmadığını belirlemeye yönelik olarak yapılan tek yönlü varyans analizi (ANOVA) sonuçları tablo $15^{\prime}$ te gösterilmiştir.

Tablo 15

Örgütsel Kimlik Için Branş Değiş̧kenine Göre Yapilan Tek Yönlü Varyans Analizi (ANOVA) Sonuçları.

\begin{tabular}{|c|c|c|c|c|c|c|c|}
\hline Ölçek & Branş & $\mathbf{N}$ & $\bar{X}$ & Ss & sd & $\mathbf{F}$ & $\mathbf{p}$ \\
\hline \multirow{18}{*}{ Örgütsel Kimlik } & Türk Dili & 98 & 3.67 & 0.92 & \multirow[t]{18}{*}{504} & \multirow[t]{18}{*}{0.586} & \multirow[t]{18}{*}{.895} \\
\hline & Din Kültürü & 20 & 3.68 & 0.65 & & & \\
\hline & Tarih & 37 & 3.79 & 0.87 & & & \\
\hline & Coğrafya & 30 & 3.49 & 0.80 & & & \\
\hline & Matematik & 84 & 3.48 & 0.85 & & & \\
\hline & Fizik & 23 & 3.72 & 0.73 & & & \\
\hline & Kimya & 29 & 3.54 & 0.71 & & & \\
\hline & Biyoloji & 20 & 3.77 & 0.77 & & & \\
\hline & İngilizce & 41 & 3.67 & 0.79 & & & \\
\hline & Beden Eğitimi & 22 & 3.57 & 0.95 & & & \\
\hline & Felsefe & 19 & 3.63 & 0.91 & & & \\
\hline & Rehberlik & 28 & 3.64 & 0.97 & & & \\
\hline & Meslek Dersi & 34 & 3.47 & 0.87 & & & \\
\hline & Bilişim & 13 & 3.68 & 0.71 & & & \\
\hline & Resim & 7 & 3.57 & 0.67 & & & \\
\hline & Almanca & 9 & 3.73 & 0.39 & & & \\
\hline & Müzik & 7 & 3.20 & 0.52 & & & \\
\hline & Toplam & 521 & 3.61 & 0.83 & & & \\
\hline
\end{tabular}

Araştırmaya katılan öğretmenlerin örgütsel kimlik algı düzeylerinin branş değişkenine göre tek yönlü varyans analizi sonucunda grup ortalamaları arasındaki fark istatistiksel açıdan anlamlı bulunmamıştır ( $p>0.5$ ). Böylece, $\mathrm{H} 6$ hipotezi reddedilmiştir.

Öğretmenlerin örgütsel kimlik algı düzeylerinin branş değişkenine göre ortalamalarının yüksek düzeyde olduğu görülmektedir. En düşük ortalama ile Müzik öğretmenlerinin $\bar{X}=3,20$ ve en yüksek ortalamanın $\bar{X}=3,79$ ile Tarih öğretmenlerinin olduğu görülmektedir.

\section{SONUÇ, TARTIŞMA VE ÖNERILER}

Araştırmaya katılan lise öğretmenlerinin örgütsel kimlik algı düzeyleri "yüksek" düzeydedir. Argon ve Ertürk'ün (2013) ilköğretim okulu öğretmenleri üzerinde yapmış olduklarıu araştırmada da öğretmenlerin örgütsel kimlik algıları yüksek düzeyde çıkmıştır. yapılan analizler incelendiğinde en yüksek ortalamanın "Bu okul hakkında konuşurken 'onlar' diye konuşmaktan ziyade 'biz' diye konuşurum." maddesi için verildiği görülmektedir. Bu durum bize okullardaki öğretmenlerin güçlü bir takım ruhuna sahip oldukları, yerleşmiş bir okul kültürünün var olduğunu, okulları ile özdeşleşme derecelerinin yüksek düzeyde olduğunu göstermektedir. Paylaşılan ortak değerler, normlar, davranış biçimleri, çalışanların örgüte bağııı̆ını geliştirip, işgören davranışlarında tutarlıı̆̆ı arttırarak örgütte birliktelik duygusu oluşmasını sağlar ve iş görenlerde "biz" duygusunun gelişmesine katkıda bulunur. Bir kültürü güçlü yapan faktör, o kültüre inanmış ve bağlanmış kişilerin örgütle özdeşleşme dereceleridir (Tiryaki, 2005, s. 161). Çalışanların çalıştıkları yerlerle ve iş arkadaşlarıyla kendilerini özdeşleştirme dereceleri örgütsel kimliğin göstergesidir. Çalışanlar eğer çalıştıkları işletmelere kendilerini yakın hissediyorlarsa ve faaliyetlerini benimsiyorlarsa, her yerde çalıştıkları iş yeri hakkında olumlu şeyler söylemektedirler (Çelik, 2007; 77). 
Araştırmaya katılan öğretmenlerin cinsiyet değişkeni ile örgütsel kimlik algıları arasında anlamlı bir ilişki olduğu tespit edilmiştir. Yapılan analizler sonucunda erkek öğretmenlerin cevaplarının ortalaması kadın öğretmenlerin cevaplarının ortalamasından daha yüksek bulunmuştur. Bu sonuç bize erkek öğretmenlerin kurumları ile daha yüksek oranda özdeşleştiklerini, okullarının kimlik tanımları ile kendilerini daha fazla tanımladıklarını ve kurum kimliği algılarının kadın öğretmenlerden daha fazla geliştiğini göstermektedir. Tüzün’ de (2006) yaptığı araştırmada algılanan örgütsel kimliğin bazı demografik değişkenlere göre farklılaştığını belirtmektedir. Yine aynı şekilde Akgül' de (2012), Argon ve Ertürk (2013) yaptıkları araştırmalarda örgütsel kimlik düzeyleri açısından, erkek öğretmenlerin örgütsel kimlik düzeylerinin kadınlara göre daha yüksek olduğunu tespit etmişlerdir.

Öretmenlerin görev yaptıkları okul türleri ile örgütsel kimlik algıları arasında anlamlı bir farklılığın olmadığı, genel liselerde görev yapan öğretmenler ile meslek liselerinde görev yapan öğretmenlerin örgütsel kimlik algılarının biribirine yakın düzeyde olduğu sonucuna varılmıştır. $\mathrm{Bu}$ durum her iki okul türünde de benzer kurumsal kimlik algılarının oluştuğu yönünde bir sonuca varmamızı sağlayabilir. Bu durum Milli Eğitim sisteminin merkeziyetçi yönetim ve bürokrasi yapısından da kaynaklanabilir. Ancak çıkan sonuç örgütsel kimlik oluşturma anlamında ideal bir durum değildir. Çünkü örgütleri biribirinden ayırt edici bir örgütsel kimlik algısına sahip olmak ideal olanıdır. Bir örgütün, bir kimliğe gereksinim duymasının başlıca nedenleri örgüt içerisinde çalışanların örgüt ile bütünleşmelerini sağlamak ve bunun yanında örgütü çalışanlarından bağımsız hale getirerek kendisi ile eşdeğer örgütler arasında fark yaratmaktır (Solmaz, 2008, s. 19). Oysa genel liseler ile meslek liselerinin benzer kimlik algılarına sahip olduklarını bir anlamda kendilerini farklılaştıran bir kimlik algısına sahip olmadıklarını görmekteyiz. Bu durum okullardaki örgütsel kimlik algısının gelişmediği şeklinde yorumlanabilecek dikkat çekici bir noktadır.

Yine araştırmaya katılan öğretmenlerin görev yeri değişkenine ilişkin örgütsel kimlik algıları arasındaki fark, yapılan analizler sonucunda anlamlı bulunmamıştır. Okul türü değişkenine ilişkin sonuca benzer bir sonuç ortaya çıkmıştır. İl merkezinde ve ilçe merkezinde görev yapan öğretmenlerin benzer kimlik algılarına sahip oldukları sonucuna ulaşılmıştır. Verilen cevapların ortalama değerlerine bakıldığında ilçe nerkezinde görev yapan öğretmenlerin az da olsa daha yüksek düzeyde bir ortalamaya sahip oldukları dikkat çekici bulunmuştur. Bu durum ilçe merkezinde görev yapan öğretmenlerin kurumsal kimlik algılarının il merkezinde görev yapan öğretmenlerden daha fazla geliştiğini göstermektedir. Illgili bazı araştırmalarda da küçük yerleşim merkezlerinde ya da daha küçük örgütlerde ortak kimlik algısı oluşturmanın daha kolay olduğu vurgulanmaktadır. Bu araştırmadaki sonuçlar da bu görüşü destekler niteliktedir. Çırpan (1999)'da işgörenlerin büyük örgütlerde kendilerini özdeşleştirmekte zorluk çektiklerini belirtmiştir.

Araştırmaya katılan öğretmenlerin örgütsel kimlik algı düzeylerinin mesleki kıdem değişkenine göre anlamlı bir farklılık oluşturmadığı görülmüştür. Ancak verilen cevapların ortalama değerleri incelendiğinde en düşük katılıma sahip değerlerin $1-5$ yıl kıdemi olan öğretmenlerden gelmiş olması, en yüksek katılımın ise $16-20$ yıl kıdemleri olan öğretmenlerden gelmiş olması dikkat çekici bulunmuştur. Aynı şekilde Argon ve Ertürk (2013) yaptıkları çalışmada benzer bulgulara ulaşmışlardır. Bu sonuç örgütsel kimlik oluşturmanın bir süreç olduğunu, zaman içerisinde çalışanların kurumları ile özdeşleşebildiklerini göstermektedir. Çünkü mesleklerinin ilk yıllarında en düşük düzeyde katılım gösteren öğretmenler 16 - 20 yıl kıdeme ulaştıklarında en yüksek düzeyde bir katılım göstermişlerdir. Aradaki süre dikkat çekicidir. Örgütsel kimlik genel olarak örgüt üyelerinin örgütleriyle ilgili algılamalarını, duygu ve düşüncelerini ifade eder. Kavram, örgütün ayırt edici değerleri ve özellikleriyle ilgili paylaşılan ortak bir anlayış olarak kabul edilir (Hatch, Schultz, 1997, s. 357). $\mathrm{Bu}$ durumun oluşmasının da bir süreç gerektirdiği bu araştırmada da açık bir şekilde 
görülmektedir. Bu anlamda Milli Eğitim Bakanlığı'nın öğretmenlerin örgütsel kimlik algılarını hedefleri doğrultusunda etkileyen çalışmalar yapmasına ihtiyaç olduğu görülmektedir. Özellikle mesleklerinin ilk yıllarında öğretmenlerin bu tür desteklere daha fazla ihtiyaç duydukları da bu araştırmanın önemli sonuçları arasındadır. Öğretmenlerin bu ihtiyaçlarının karşılanmasına yönelik olarak; özellikle örgüt vizyonu'nun ve örgüt misyonu'nun öğretmenler ile daha etkili bir şekilde paylaşılması gerekmektedir.

\section{KAYNAKLAR}

Ak, M. (1998). Kurumsal kimlik ve imaj. İstanbul, Işıl ofset Itd.

Akgül, S. (2012). Illköğretim okulu öğretmenlerinin örgütsel kimlik algıları ile örgütsel bağlııkları arasındaki ilişki. Yayinlanmamiş yüksek lisans tezi. Sakarya Üniversitesi Eğitim Bilimler Enstitüsü.

Argon,T. ve Ertürk, R.( 2013). İlköğretim okulu öğretmenlerinin içsel motivasyonları ve örgütsel kimliğe yönelik algıları. Kuram ve uygulamada eğitim yönetimi, 19(2),159-179.

Ayyıldız, H. ve Cengiz, E. (2006). Pazarlama modellerinin testinde kullanılabilecek yapısal eşitlik modeli (YEM) üzerine kavramsal bir inceleme, Süleyman Demirel Üni. iliBF Dergisi, 11, 1, 63-84.

Bayram, N. (2010). Yapısal eşitlik modellemesine giriş amos uygulamaları. Bursa, Ezgi Kitabevi.

Biber, A. (2003). Halkla ilişkilerde temel kavramlar. Ankara, Nobel Yayınları.

Çırpan, H. (1999). Örgütsel öğrenme iklimi ve örgüte bağlılık ilişkisi: bir alan araştırması. İstanbul, İstanbul Üniversitesi. Sosyal Bilimler Enstitüsü, Yayınlanmamış doktora tezi.

Çokluk, Ö., Şekercioğlu, G. ve Büyüköztürk, Ş. (2010). Sosyal bilimler ıçin çok değiş̧enli Istatistik. Ankara, Pegem Akademi.

Downey, S. M. (1986-1987). The relationship between corporate culture and corporate identity. PublicRelations Quarterly, Volume 31, No: 4

Empson, L. (2004). Organizational identity change: managerial regulation and member Identification in an accounting acquisition. Accounting, Organizations and Society, 29, 759-781.

Ertürk, A. (2003). Örgütsel iletişim ve adalet algılarının örgütsel kimlik algısı üzerindeki etkileri. Yönetim Araştırmaları Dergisi, 3, 2, 147-170.

Fombrun, C. J., Cees, V.R.(2003). Fame \& Fortune: How successful companies build winning reputations. financial times prentice hall books, Upple Saddle River, NJ.

Güleç, C. (2005). Evrensel bir kimlik mümkün mü?, Türkiye günlüğü, Sayı: 83, Ankara, 7276.

Gülsünler, M. E. (2007). Kurum kimliği süreci ve işleyişi üzerine teorik ve uygulamalı bir çalışma. Selçuk Üniversitesi Sosyal Bilimler Enstitüsü Dergisi, 17, 281-294.

Hatch, M. J., Schultz, M. (1997). Relations between organizational culture, identity and Image. European Journal of Marketing, 31, 5/6, 356-365.

Hündür, B. (2006). Örgütsel imaj ve üye bütünleşmesi, http://www.ikademi.com/orgutseldavranis/1120-orgutsel-imaj-ve-uye-butunlesmesi.html, Erişim Tarihi: (06.09.2008).

Karasar, N. (2002). Bilimsel araştırma yöntemleri. Ankara, Nobel Yayıncılık.

Karasar, N. (2005). Bilimsel araştırma yöntemleri. Ankara, Nobel Yayıncılık. 
Korkmaz, M. (2007). Örgütsel sağlık üzerinde liderlik stillerinin etkisi. Kuram ve Uygulamada Eğitim Yönetimi Dergisi, 49, 57-91.

Marwick, N., Fill, C. (1997). Towards a framework for managing corporate identity. European Journal of Marketing, Vol:31, No:5, 396-409.

Okay, A. (2000). Örgüt kimliği, Ankara, İstanbul, MediaCat Yayınevi.

Olins, W. (1990). Guide to corporate identity. Black Bear Press, London, 108.

Şimşek, Ö.F. (2007). Yapısal eşitlik modellemesine giriş: Temel ilkeler ve LiSREL uygulamaları. Ankara, Ekinoks, 4-22.

Solmaz, F. (2008). Belediyelerde yönetime katılım açısından bilgi edinme hakkı uygulaması ve ıstanbul büyükşehir belediyesi örneği. Yayımlanmamış yüksek lisans tezi, Marmara Üniversitesi Sosyal Bilimler Enstitüsü Kamu Yönetimi Ana Bilim Dalı, İstanbul.

Sümer, N. (2000). Yapısal eşitlik modelleri: Temel kavramlar ve örnek uygulamalar. Türk Psikoloji Yazıları, 3(6), 49-74.

Tiryaki, T. (2005). Örgüt kültürünün örgütsel bağlılık üzerine etkileri. Yayımlanmamış yüksek lisans tezi, Dumlupınar Üniversitesi, Sosyal Bilimler Enstitüsü, Yönetim Organizasyon Ana Bilim Dalı, Kütahya.

Tüzün, i. (2006). Örgütsel güven, örgütsel kimlik ve örgütsel özdeşleşme iiişkisi; uygulamalı bir çalışma. Yayınlanmamış doktora tezi. Gazi Üniversitesi Sosyal Bilimler Enstitüsü. Ankara.

Van Tonder, C. L. (2004). Below-the surface and powerful: The emerging notion of organization identity. Organization Development Journal, 22, 2, 68-78. 


\section{SUMMARY}

In our age the importance of having a positive identity is so important for all kinds of organizations. There has been very hard competition among the organizations. In order to be superior than the other organizations, a positive identity is a 'must' for all kinds of organizations. For this reason educational organizations also must have an organizational identity and this identity should develop and direct the organization. In this concept having a strong identity is also a necessity for high schools because they prepare the students for their professions or a higher education. Searching of the interpretation of this identity by the teachers is also so important.

The aim of this research is to determine the organizational identity perception of high school teachers. For this purpose the hypothesis below were developed.

H1) Organizational identity perception level of high school teachers is "high" level.

$\mathrm{H} 2$ ) There are differences between the organizational identity perceptions of high school teachers and gender.

H3) There are differences between the organizational identity perceptions of high school teachers and the type of school.

H4) There are differences between the organizational identity perceptions of high school and their place of duty.

H5) There are differences between the organizational identity perceptions of high school teachers and their professional seniority.

H6) There are differences between the organizational identity perceptions of high school teachers and their branches.

The target population of this research, which is in descriptive relational scanning model, working in high schools in 2012-2013 academic year in the city of Malatya. The sample of the research consists of 2321 teachers who were selected randomly from the target population with simple cluster sampling method. The questionnaires that were filled up 521 teachers were returned back and analyzed. The data were analyzed by SPSS 20.0 package programme. As the data collection tool "Organizational identity scale" which was developed by Jones and Volpe(2010) was used.

H1) Whwn we look at the findings belong to the $1^{\text {st }}$ hypothesis, mean value of the organizational identity perceptions of the teachers working at high school is $\left(x^{-}=3,60, \pm=1,19\right)$ "high" level. So the $1^{\text {st }}$ hypothesis is accepted.

H2) There are differences between the genders and organizational identity perceptions of high school teachers;

There is a meaningful difference between the genders and organizational identity perceptions of high school teachers $(p<0,05)$. As a result of this finding the $2^{\text {nd }}$ hypothesis is also accepted. The organizational identity perception values of male participants are higher than the female participants. While the mean value of male participants is 3,69 the mean value of female participants is 3,44 .

H3) There are differences between the type of schools and identity perceptions of high school teachers. There isn't a meaningful difference between the type of schools and organizational identity perceptions of high school teachers $(p>0,05)$. So the $3^{\text {rd }}$ hypothesis is rejected.

H4) There are differences between the place of duty and the identity perceptions of high school teachers. There isn't a meaningful difference between the place of duty and the identity perceptions of high school teachers $(p>0,05)$. So the $4^{\text {th }}$ hypothesis is also rejected.

H5) There are differences between the seniority of teachers and the identity perceptions of high school teachers. This hypothesis was analyzed by One Way Anova tests. There aren't any differences between the values of the groups $(p>0,05)$. So the $5^{\text {th }}$ hypothesis is rejected. 
H6) There are differences between the branches of teachers and the organizational perceptions of high school teachers. As a result of the One Way Anova test, it was found that there aren't and differences between the branch groups $(p>0,05)$. So the $6^{\text {th }}$ hypothesis is rejected.

The identity perceptions of high school teachers are analyzed in some variables in this study.

As a result; It was found a meaningful relation between the gender of teachers and the identity perceptions of high schools. The mean values of male teachers are higher than the values of female teachers. This result has shown us that the male teachers has more organizational identity perceptions than the female teachers.

When we look at the relation between the type of schools and the identity perceptions of high school teachers, we see that there is no difference between them.

There is also no difference between the place of duty of teachers and the identity perceptions of high school teachers. At the same time there is a similar result between the type of schools variable and the identity perceptions of the teachers. It was found that nearly the same values between the perceptions of participants working in towns.

It was also found that there is no difference between the seniority of teachers and the organization values of the participants. But when we look at the mean values of the perceptions of the teachers, we see the lowest values for the group of 1-5 years seniority and the highest mean values for the group of 16-20 years seniority. As a result of these findings, it is clear that Ministry of Education should develop the activities improving the identity perception level of the high school teachers. The teachers, who are especially early years in their carrier, need such kinds of supports more. 